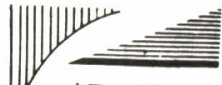

解 説

\title{
ディーゼル船排ガスェコノマイザの 外部污れとスートファイア*
}

\section{西川栄 - ${ }^{* *}$}

\section{1. はじめに}

排ガスエコノマイザによるディーゼル主機排熱回収は, 最む有効な省エネルギ策の一つであり，以前から多用さ れているが, 省エネルギ要請が強くなるに伴い, 最近は 排熱回収効果をあげるためにさまざまな新しい排ガスエ コノマイザシステムが工夫されている. てれら新しいシ ステムにみられる大きな特徴は蒸気圧力の多段化とフィ ン付管の普及にあるといえよう. 多段化は, ターボ発電 のサイクル効率も考慮した最適圧力で排エコを運転した 場合，ピンチポイントでの排ガス温度がまだ高いので， さらに低圧の伝熱回路を追加しててのピンチポイント以 下の排ガス保有熱を回収しようとするもので，2段圧力 方式が一般化しているが，3段圧力方式のあのあある. 低圧蒸気は主に雑用熱源に消費されるが, 発電タービン を混圧方式にして発電用に使用する屯のも出はじめてい る.また主機用過給空気の冷却を排エコ給水予熱で行い, 排ガス以外の熱損失回収も排エコシステムに組み込んで 行うものもでてきている. とのように最近の排エコシス テムは少しであ回収熱量をあげようとして複雑なシステ ムになりつつあり, これに伴って, 各系統の流量制御, 温度制御など自動制御要素を中心に機器類の数も増えて トラブルや故障発生の可能性が大きくなっており, 同時 に運転操作も複雑になってきている.

フィン付管の使用は, 上述のように熱回収量を増すた めに所要伝熱面積が大きく増加してきたことの反映であ る. 裸管では排エコ寸法が過大になるのである. フィン 付管の使用で問題になるのは外部污れである. 外部污れ は裸管でも問題であるが, しかしフィン付管の場合, 伝 熱面積 (付着物付着面積)が大きいとと, フィンとフィン の間に付着物が堆積しやすいこと, ガス通路が複雑であ ることなどのために裸管よりも外部污れが発達しやすい し，またその影響にもより敏感なのである. 外部污れに よる障害はドラフトロスの増大, 伝熱性能の悪化, ガス 通路閉塞などさまざまであるが, 排エコで問題にされる 障害の一つはスートファイアであろう. スートファイア は周知のように伝熱面に堆積したすすが発火する火災事 故であるが,ひどい場合には大量の伝熱面が溶損して排 エコは使用不能になり，その復旧のために船の運転を長

* 原稿受付 昭和 58 年 6 月 6 日

** 正会員 神戸商船大学(神戸市東灘区深江南町 5-1-1)

日本舶用機関学会誌 第 18 巻 第 9 号
期にわたって停止しなければならないという大事故に到 る.フィン付管の使用に伴い, このスートファイア事故 が問題になる可能性がある.

このように最近の排エコシステムは省エネルギに対応 する新しいシステムの導入に伴って, 新たな問題も生じ てきているようである. ここではその中であ重要と思わ れる外部污れとスートファイアについて少し述べてみた ().

\section{2. スートファイアの事故例}

表 1 は比較的最近にみられたいくつかのスートファイ ア事故の概要である. 表をみると船種や排ガス温度, 排 エコ設計条件にはとくに特徴はみられないが，いずれも $\mathrm{T} / \mathrm{G}$ 付フィン付管使用の大形排エコで生じている. 事 故内容をみると, いずれも蒸発部を中心に大量のボイラ 管が溶損している. 図 1 の写真は溶損したボイラ管の様 子を示した例であるが，かなりひどいあのである．この ように溶けてしまうと溶損部分は一部であっても，その 付近の管や構造部分は熱で変形するし, 下に位置する過 熱器などにも上から流れ落ちてきた溶塊物が堆積したり して, 被害は排エコ全体に及ぷ. スートファイアは蒸気 王力やドラム水位が異常に低下したり, 煙突から白煙 (蒸気) が生じたり, あるいは排ガス温度が異常に上昇し たりすることで発見されるととが多いが, これらの徴候

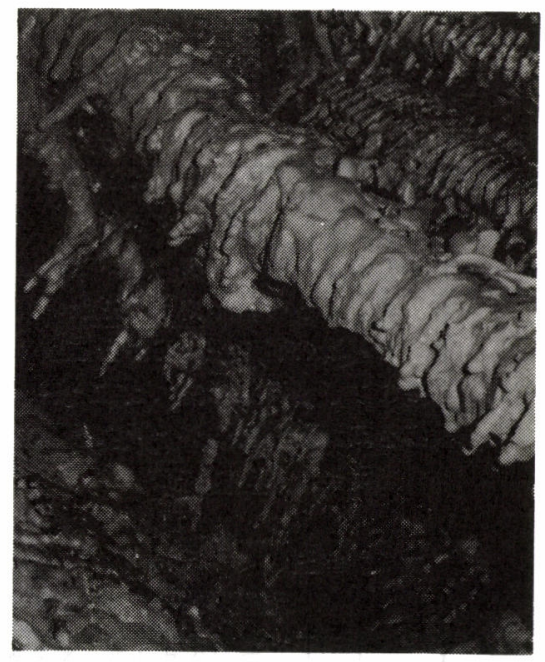

図1 スートファイアによる蒸発管溶損の例 


\begin{tabular}{|c|c|c|c|c|c|c|c|c|c|c|}
\hline 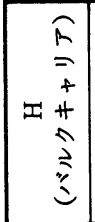 & 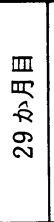 & 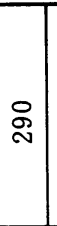 & 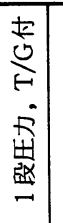 & L & 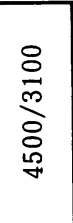 & 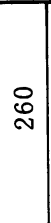 & 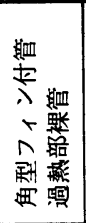 & 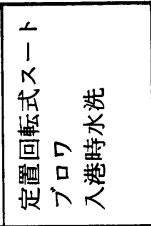 & 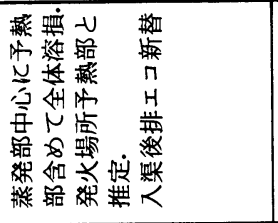 & 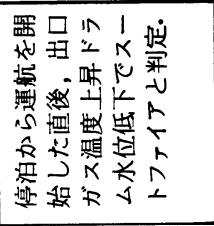 \\
\hline $\begin{array}{l}\widehat{R} \\
0 . \\
\hat{x}\end{array}$ & 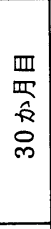 & 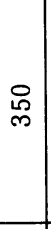 & 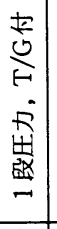 & مْ & $\begin{array}{l}\text { 号 } \\
\text { 另 } \\
\text { 号 } \\
\text { 品 }\end{array}$ & $\begin{array}{l}\stackrel{8}{ } \\
\stackrel{\sim}{0}\end{array}$ & 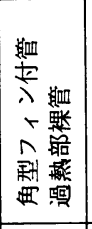 & 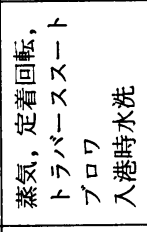 & 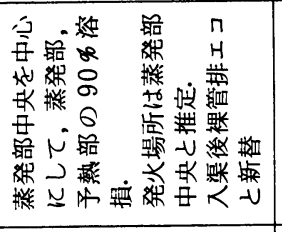 & 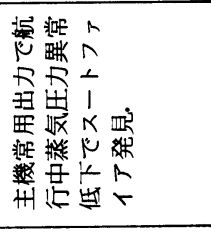 \\
\hline $\begin{array}{c}\nwarrow \\
1 \\
\lambda \\
\lambda \\
\pi\end{array}$ & 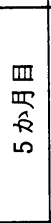 & $\stackrel{\infty}{\stackrel{\infty}{N}}$ & 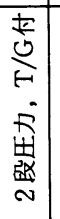 & 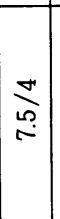 & 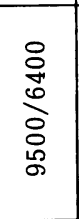 & 怘 & 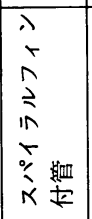 & 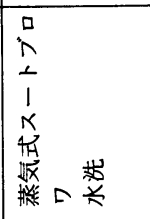 & 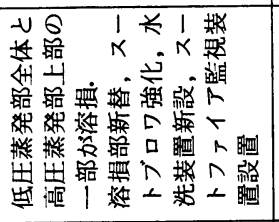 & 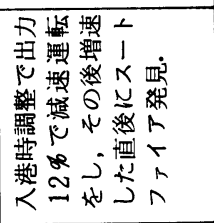 \\
\hline 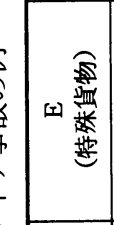 & 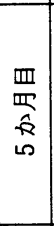 & ঙิ & 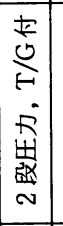 & 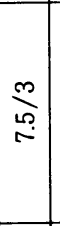 & 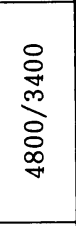 & $\stackrel{\circ}{\circ}$ & 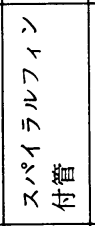 & 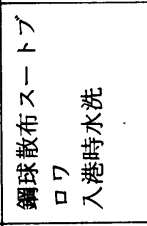 & 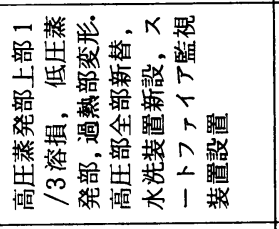 & 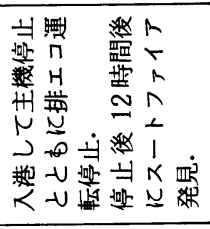 \\
\hline $\begin{array}{l}\widehat{R} \\
0 \\
\hat{x}\end{array}$ & 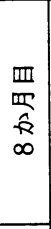 & $\frac{n}{m}$ & 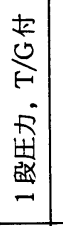 & 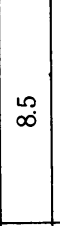 & 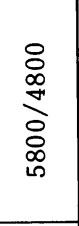 & $\underset{\sim}{\stackrel{D}{N}}$ & 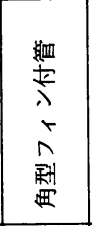 & 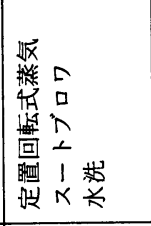 & 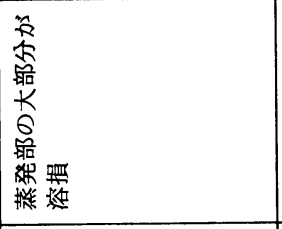 & 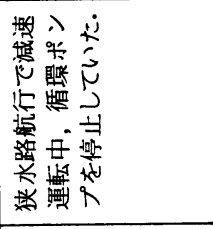 \\
\hline $\begin{array}{l}\widehat{E} \\
0 \\
\hat{N}\end{array}$ & $\begin{array}{l}\text { 四 } \\
\text { 吕 } \\
\hat{R} \\
\text { D } \\
\rightarrow\end{array}$ & $\frac{\sim}{m}$ & 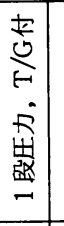 & 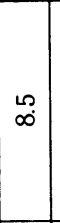 & 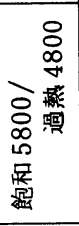 & $\stackrel{L}{\underset{N}{N}}$ & 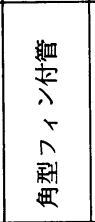 & 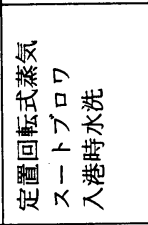 & 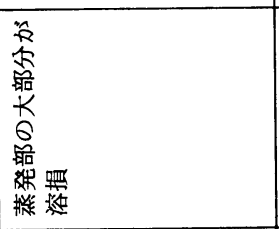 & 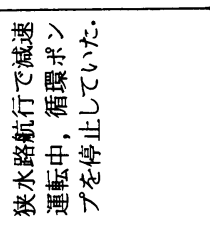 \\
\hline 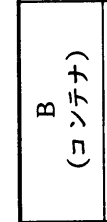 & 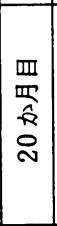 & 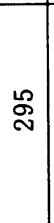 & 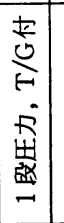 & - & 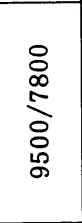 & 号 & 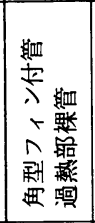 & 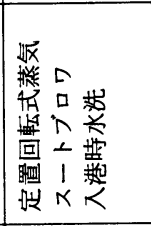 & 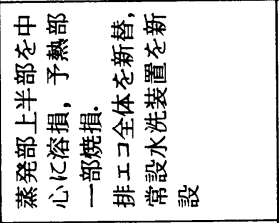 & 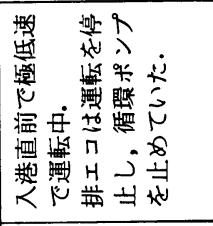 \\
\hline 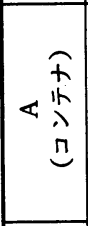 & $\begin{array}{l}\text { 血 } \\
\text { 惫 } \\
\hat{R} \\
\underline{m} \\
\end{array}$ & $\stackrel{2}{\stackrel{N}{2}}$ & 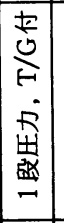 & r & 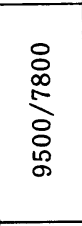 & $\stackrel{\mathscr{N}}{\underset{N}{N}}$ & 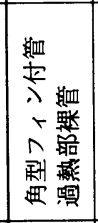 & 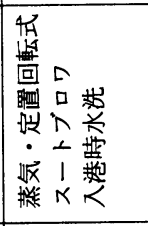 & 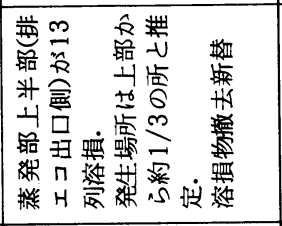 & 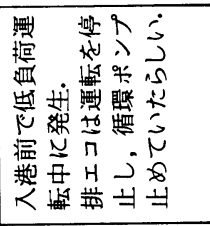 \\
\hline \multirow[t]{2}{*}{ 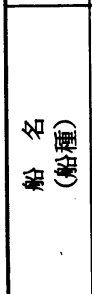 } & \multirow[t]{2}{*}{ 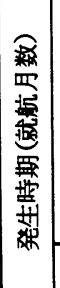 } & 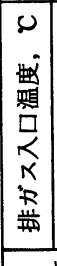 & $\begin{array}{l}4 \mathrm{H} \\
\text { 踢 }\end{array}$ & 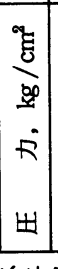 & 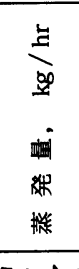 & 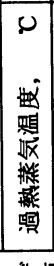 & 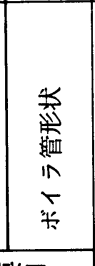 & \multirow[t]{2}{*}{ 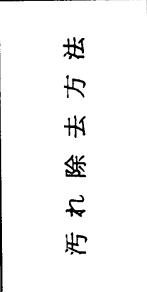 } & \multirow[t]{2}{*}{ 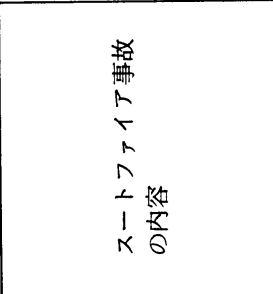 } & \multirow[t]{2}{*}{ 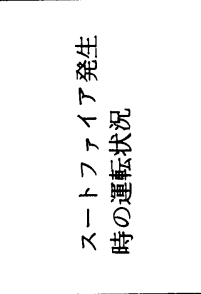 } \\
\hline & & & & & & & & & & \\
\hline
\end{tabular}


を認めた時はすでにスートファイアはかなり進行してお り, いわば手遅れの状態で堆積したすすが燃え切ってし まうまで待つしかないというのが実情である. 発見した 時にはすでにボイラ管の溶損が始まっていて, スートフ アイアそのものは発見時点よりかなり以前から始まって いるのであろう. かかる状態になると，スートファイア 中はあちろん主機を停止しなりればならないが, 鎮火後 の復旧作業も大変である. 表の諸例ではとりあえず本船 で溶損チューブを切り出して排ガス通路を確保し, バイ パス配管を施すなどの応急処置を施して，入港するまで の主機運転を可能にしているが, その応急処置にでも数 日を要している. その後の完全な復旧対策は溶損部新替 工事ということになるが, 修理が不可能で排エコ全体を 新替したという例も少なくなく，長期の工事期間と多く の費用を要している. スートファイアは船全体からみる とごく部分的な付属品である排エコに生ずる事故である が，いったん生ずると大規模な事故に到る.

表をみていくつかの特徴がうかがえる. 第 1 は, 溶損 部分が圧倒的に蒸発部, それも排エコ出口側蒸発部上半 部分に多くみられることである. 表の排エコはいずれあ 伝熱面は予熱部, 蒸発部, 過熱部を有しているが, 予熱 部が一部又は全部が溶損した船は $\mathrm{B}, \mathrm{G}, \mathrm{H}$ の 3 船のみで あり, 過熱部溶損の例はみられない. 蒸発部はすべての 船で溶損しているが, それらの様子からみると, スート ファイアは蒸発部の上部 $1 / 3$ から中央部辺りにかけて発 生する例が多いように思われる. 予熱部が発生場所とす る船はH 1 船のみでそれも推定である. 第 2 はスートフ アイア発生時の排エコ運転状況についてであるが, 残念 ながらこれについては詳しいことがわからないのが大部 分である.ささきにもふれたように、スートファイアを発 見した時にはすでにスートファイアは何時間も前に発生 していた可能性が強く, 発生時点の情況亡なるとなおさ らそうである. しかし表によれば, 減速或は低負荷運転
中で排エコを運転せず，循環ポンプを止めていたとみら れる船が A， B , C , D , F と多いことが注目される。乙 れらは低負荷運転中とはいえ, 排エコは“空だき”運転の 状態になっていたよみなされる．また $\mathrm{E}, \mathrm{H}$ 船は情況が 似ており，停泊中にスートファイアが発生していたよう である．想像であるが，主機停止時に堆積したすすが着 火状態にあったとしたら，主機停止で排ガスによる加熱 はおさまってもすす燃焼による加熱は続くだろう．この 時排エコの運転を止め循環ポンプを止めると事実上. “空 だき”のような情態が生じるだろうＥ（EH船はこのよ うな情況でスートファイアになったのではなかろうか. こうみると, 途中の過程はさまざまだが何らかの原因で 空だき状態になった時に，スートファイアが生じること が多いといえそうである. 第 3 は事故発生時期で, 就航 後比較的短期間に発生している例が多いことである. こ のことは排エコが污れやすく，着火しやすい船のあるこ とを意味しているのかあしれない. スートファイアを起 している排エコの型式は特定されないから，原因は主機 にあろう.すなわちすすの発生しやすい主機があり，そ のような船ではスートファイアに要注意ということであ る.

以上いくつかのスートファイアの事故例をみて, 事故 にいたる特徵点と思われるあのをあげてみた。これらを 念頭において, 以下スートファイア発生原因や防止策に ついて考えてみたい.

\section{3. スートファイアの可能性}

3.1 外部付着物の性状表 2 にいくつかの排工 コの採取付着物の化学定量分析例を示す. 表による之付 着物の主成分は硫黄, 鉄, カルシウム成分及び炭素であ る.ナトリウムやバナジウムは少なく，典型的な低温伝 熱面の付着物の特徵が現われている. 鉄, カルシウムは X線回折分析によれば硫酸鉄，硫酸カルシウムであり，

表 2 排ガスエコノマイザ外部付着物の化学成分分析例

\begin{tabular}{|c|c|c|c|c|c|c|c|c|c|c|}
\hline 船 名 & 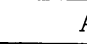 & & B & & $\mathrm{C}$ & $\mathrm{D}$ & E & & $\mathrm{F}$ & \\
\hline 分析項目 ${ }^{\text {採 }_{\text {垃置 }}}$ & $\begin{array}{l}\text { 過熱部 } \\
\text { 下 }\end{array}$ & $\begin{array}{l}\text { 過熱部 } \\
\text { 表 層 }\end{array}$ & $\begin{array}{l}\text { 排ガス } \\
\text { 入口側 } \\
\text { ダンパ } \\
\text { 表面 }\end{array}$ & $\begin{array}{l}\text { 蒸発部 } \\
\text { 排ガス } \\
\text { 出口側 }\end{array}$ & $\begin{array}{l}\text { 蒸発部フ } \\
\text { イン間 } \\
\text { 排ガス入 } \\
\text { 口側 }\end{array}$ & 蒸発部 & $\begin{array}{l}\text { 蒸発部下層 } \\
\text { 排ガス入口側 }\end{array}$ & $\begin{array}{l}\text { 蒸発部表層 } \\
\text { 排ガス入口側 }\end{array}$ & $\begin{array}{l}\text { 主機排気 } \\
\text { 弁内出口 } \\
\text { フランシ } \\
\text { 付近 }\end{array}$ & $\begin{array}{l}\text { 水洗水に } \\
\text { よるはく } \\
\text { 離スート }\end{array}$ \\
\hline $\mathrm{pH}(\mathrm{g} / 100 \mathrm{ml})$ & 2.2 & 3.3 & 2.3 & 2.9 & 2.6 & - & 3.0 & 3.0 & - & - \\
\hline しpく熱減量(多) & 62.3 & 27.8 & 70.6 & 79.8 & 79.7 & 90.4 & - & - & 91.4 & 78.8 \\
\hline $\mathrm{S}\left(\mathrm{SO}_{3}\right), \quad \not 0$ & 45.0 & 45.0 & 35.2 & 24.8 & 9.20 & 9.90 & 11.5 & 22.2 & 16.8 & 15.5 \\
\hline $\mathrm{Fe}\left(\mathrm{Fe}_{2} \mathrm{O}_{3}\right)$, क & 4.12 & 1.27 & 19.8 & 14.7 & 13.1 & 3.91 & 8.20 & 9.16 & - & 13.6 \\
\hline $\mathrm{V}\left(\mathrm{V}_{2} \mathrm{O}_{5}\right), \quad \not$ & 5.04 & 5.16 & 2.69 & 0.83 & 0.55 & 0.40 & - & - & - & 8.70 \\
\hline $\mathrm{Ni}(\mathrm{NiO}), \quad \not$ & 0.68 & 0.91 & 0.55 & 0.16 & 0.08 & - & - & - & - & - \\
\hline $\mathrm{Ca}(\mathrm{CaO}), \quad$ \% & 10.3 & 28.0 & 3.92 & 1.79 & 3.58 & 2.57 & 1.52 & 4.32 & - & 25.0 \\
\hline $\mathrm{Na}\left(\mathrm{Na}_{2} \mathrm{O}\right), \quad \%$ & 1.14 & 1.76 & 1.03 & 0.35 & 0.30 & - & - & - & - & - \\
\hline $\mathrm{C}$ & 10.7 & 8.80 & 3.10 & 20.9 & 31.2 & 43.9 & 76.1 & 62.9 & 39.5 & 41.6 \\
\hline
\end{tabular}


硫酸カルシウムの存在はシリンダ油の影響を示すもので ある.硫酸鉄の存在は排ガス中の硫酸の凝縮が生じてい ることを意味し，蒸発部のような温度域であ硫酸の凝縮 から完全にまぬがれていないととを示している. しかし 過熱部では当然ながらての成分は極めて少ない。硫酸が 凝縮すると伝熱面がぬれた状態になるから，いわゆるす すなど他の燃焼生成物の付着を促進するが，一般に過熱 部で污れが少なく, 蒸発部, 予熱部之雾囲気温度が低く なっていく排ガス下流側に位置する伝熱面程污れが多く なっていく傾向がみられ，てのことを裏づけている.

注目されるのは, 未燃炭化水素成分の存在を示す炭素 の含有量である．表によると過熱部や入口側ダンパなど 高温域ではそれ程多くないが, 蒸発部の付着物では高く, 多いむのは $70 \%$ を越えている. そこで付着物中の炭素 含有量を調べたデータをみてみると図 2 のようであり， $60 \%$ 以上を占めるあのが 44 点中 16 点もあり，かなり 高い含有量を示している．発熱量を調べたデータはあま り見当らないが, 炭素含有量之の関係でみると図 3 のよ うである.データは 4 点しかないが, 炭素含有量とは強 い相関がみられる. 図から推定すると炭素含有量が 50 \% を越えると発熱量は $3000 \mathrm{kcal} / \mathrm{kg}$ 以上で，都市でみな どの発熱量よりも大きくなり，80\%では低質の石炭と同 程度の熱源になるといえる。

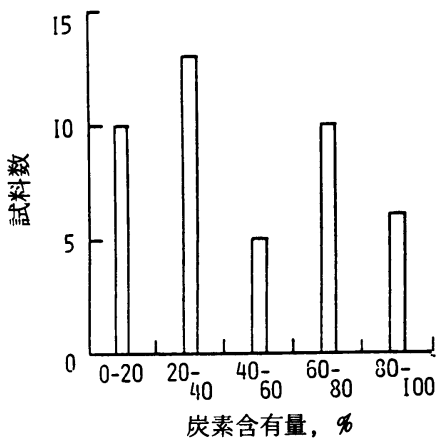

困 2 外部付着物中の炭素含有量 調査試料数 20 船 44 点

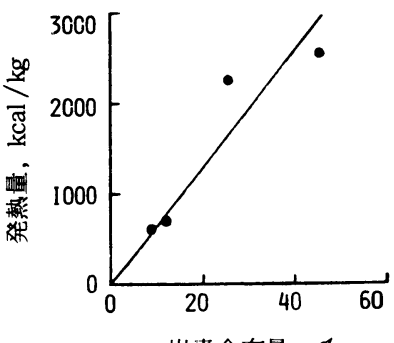

炭素含有量, 历

図 3 外部付着物発熱量之炭素含有量 之の関係
3.2 付着すす発火の可能性 困 4 は排エコ付着 物の発火点を調べた結果である. 図のデータは示差熱分 析計で発熱成分が減量しはじめる点を発火点としたもの， あるいは付着物をのせた鉄板を下から加熱し，鉄板上の 付着物が発火する時の鉄板温度を発火点としたものなど いろいろな結果が含まれているが，それでも図から判断 すると排ガス温度とほとんど変らないか，それ以下の発 火点を有する付着物が相当存在しており，注目される. 付着物表面の温度はどの程度になっているのであろうか。 ガス側熱伝達率 $h$, 排ガス温度 $t_{\mathrm{g}}$, 付着物外面温度 $t_{\mathrm{f}}$, 管壁又はフィン外面温度 $t_{\mathrm{w}}$, 付着物厚さ $d_{\mathrm{f}}$, 付着物熱 伝導率 $k_{\mathrm{f}}$ とすると,

$$
h\left(t_{\mathrm{g}}-t_{\mathrm{f}}\right)=\left(k_{\mathrm{f}} / d_{\mathrm{f}}\right)\left(t_{\mathrm{f}}-t_{\mathrm{w}}\right)
$$

であるから、

$$
\frac{t_{\mathrm{g}}-t_{\mathrm{f}}}{t_{\mathrm{g}}-t_{\mathrm{w}}}=\frac{1}{1+\left(h \cdot d_{\mathrm{f}} / k_{\mathrm{f}}\right)}
$$

となる. これを $h=105 \mathrm{~W} / \mathrm{m}^{2} \cdot \mathrm{K}\left(90 \mathrm{kcal} / \mathrm{m}^{2} \cdot \mathrm{hr} \cdot \mathrm{C}\right)$ として $k_{\mathrm{f}}$ をパラメータにしてみると図 5 のようである

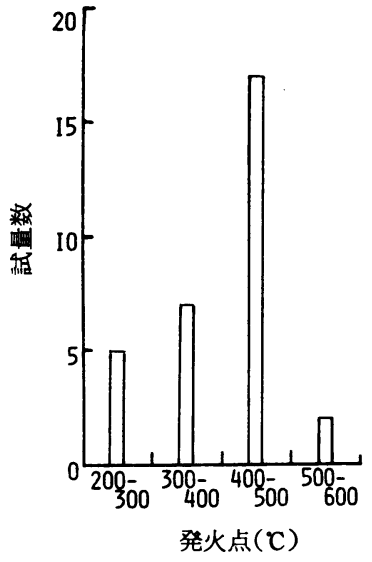

図 4 外部付着物の発火点 調査試料数 18 船 31 点

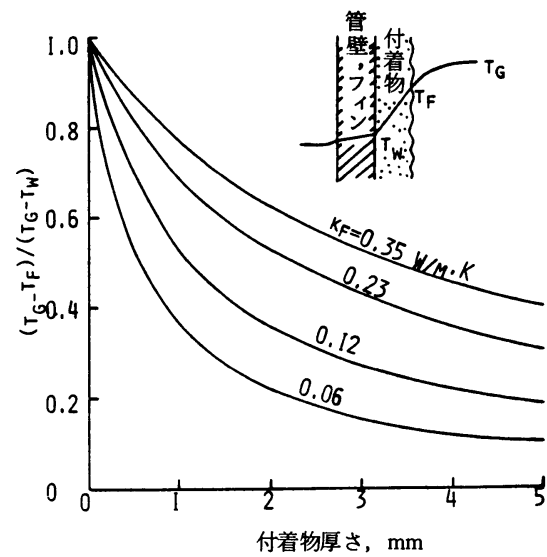

図 5 外部污れ厚さと付着物表面温度との関係 
$k_{\mathrm{f}}$ がどの程度の值かわからないが, 石炭ボイラの粉状 付着物の場合 $0.06 \sim 0.12 \mathrm{~W} / \mathrm{m} \cdot \mathrm{K}(0.05 \sim 0.1 \mathrm{kcal} / \mathrm{m}$ ・ $\left.\mathrm{hr} \cdot{ }^{\circ} \mathrm{C}\right)$ とする測定データがあるので ${ }^{1,2)}$, ここであその 程度と仮定する. $t_{\mathrm{g}} 300^{\circ} \mathrm{C}$, 管内流体温度 $165^{\circ} \mathrm{C}(0.69$ $\mathrm{MPa}, 6 \mathrm{~kg} / \mathrm{cm}^{2}$ 蒸気飽和温度相当)とすると, 付着物 外面温度は裸管で $d_{\mathrm{f}}=1 \mathrm{~mm}$ で $250^{\circ} \mathrm{C} ， 3 \mathrm{~mm}$ で $275^{\circ} \mathrm{C}$ 程度になる.フィン付管ではフィン先端温度は, ここで 考えているような伝熱条件であれば 40〜 $50^{\circ} \mathrm{C}$ は高いと 推定できるから，フィン先端付近の付着物外面温度は $d_{\mathrm{f}}=1,3 \mathrm{~mm}$ で $265,280^{\circ} \mathrm{C}$ 程度となり, ほとんどガス 温度に近くなる. あっとも, 温度条件からみてフィン先 端は污れは発達しにくい所ではある.

污れの量はどの程度になるのであろうか, 少しふるい が図6はスートファイアを起した(ただしてのスートフ ァイアはボイラ管溶損にまで到っていない)フィン付管 使用排エコの航海中のドラフトロスの変化をみたもので ある(この排エコは污れがひよ゙くて問題になった例であ る $)^{3)}$. 図によるとドラフトロスが大きくなった所でスー トファイアを起している. 同船ではドラフトロスが 220 mm Aq を越えるとスートファイアを起しやすいとして, $200 \mathrm{mmAq}$ 以上になると水洗を実施するようにしてい たということである. この排エコのクリーン時のドラフ トロスは $100 \mathrm{mmAq}$ とみれるから，污れによってドラ フトロスが 2 倍程度になるとスートファイアの心配あり， と判定していたということになる.

図 7 は污れによってどの程度ドラフトロスが増大する か, 付着厚さとの関係をみたものである. 図は簡単に考 え，伝熱面全体に一様な厚さで付着物が堆積するとし， その分ガス通路面積が減少してガス流速が増大するとみ,

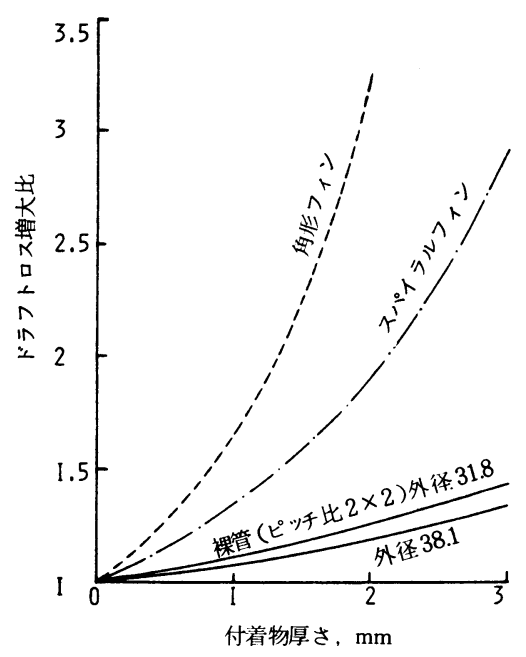

図 7 外部污れによるドラフトロスの増大

その流速増大分に応じてドラフトロスが増大するとして 計算したものである. 裸管と比較してフィン付管群のド ラフトロスは污れに敏感であるととがわかる. 図による とドラフトロスがクリーン時の 2 倍を越えるには, フィ ン付管で 1 2 $\mathrm{mm}$ の厚さに污れが発達する必要がある. この厚さは全表面に一様に付着すると想定した值である から，局所的にはもっと厚くなるととになろう。

現在使われているフィン付管のフィンピッチは $10 \mathrm{~mm}$ オーダである. したがってとの程度にドラフトロスが増 大すると,フィンとフィンとの間が部分的につまる程に 污れが発達しているといえる.であるから，うえの污れ

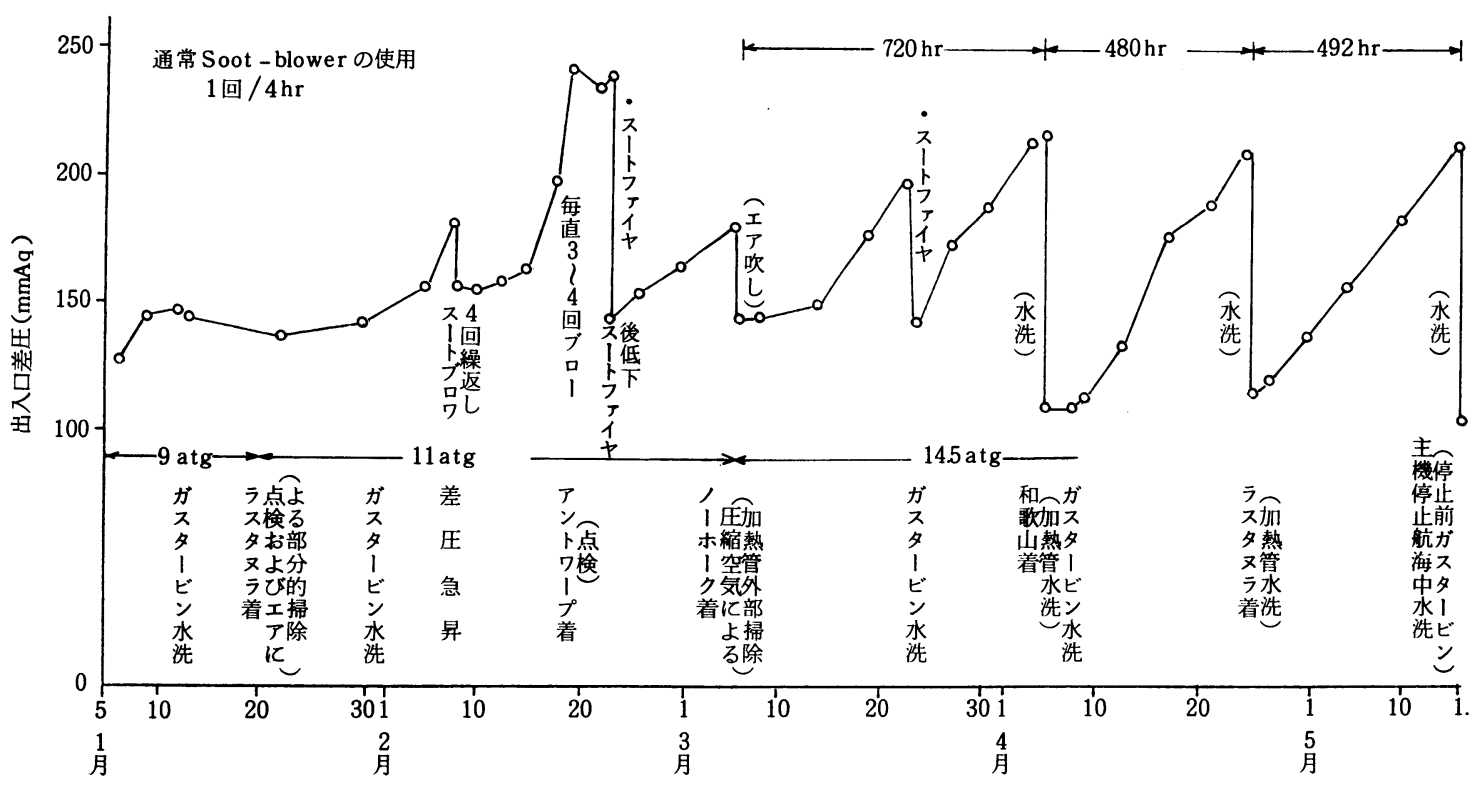

困 6 就航船の排ガスエコノマイザのドラフトロス変化の一例 ${ }^{3)}$ 
厚さと付着物外面温度の関係からみると, 付着物の性状 (炭素含有量)によっては, 外面温度が発火点を越える状 態になっている場合も想定されよう.つまり何か発火源 があれば，排エコ内に堆積したすすは容易に着火する場 合があるといえる。

発火源については火の粉状態になったすすが考えられ る. 前述のような性状のすすは主機で形成され, 排エコ 上流の, 排エコより雾囲気温度の高い所から高速で飛来 してくるのであるから, 一部は火の粉のままで排エコに 達する可能性があろう.したがって発火源も存在すると みておいた方がよさそうで, 発火源を断って堆積したす すの発火を防止するのは困難といえよう.

\section{3 伝熱面溶損の可能性的ようにディーゼ} ル主機のすすの性状からみて，付着物が発火する可能性 が存在する. しかしたとえすすが発火してあボイラ管内 に午水が循環していれば，ボイラ管が溶けてしまう写真 にみたようなひどい焼損にいたることはまず考えられな い. せいぜい煙突から大量の火の粉がでたという，図 6 の排エコのスートファイアのような程度でおさまること は，恐らく間違いないであろう. 伝熱面溶損というよう な深刻な事故に到るには，すすの発火と同時に，ボイラ 管内面が “乾く”状態が形成されていたと考えねばなら ない。

事例の所でみたように、スートファイアの発生場所は 蒸発部，とくに蒸発部中央から排ガス出口側であること が多い. 污れ状況などを各伝熱セクションで簡単に比較 してみると表 3 のようである．表でみると温度的には過 熱部が最む厳しく，発火源にもさらされやすいし，また すすが発火すれば管内面は乾いているから，最す焼損し やすい条件にある. しかし過熱部は污れが少なく燃える あのがないので，あう一つの条件が揃わない．他方予熱 部は污れが最も多い.しかし予熱部は沸騰しない条件で 設計されているから、設計条件通り運転されているなら ば管内面が乾く状態は，たとえポンプが止まっても生じ にくく，てのセクションも両条件が揃わない．乙のよう に比較してみると上述の 2 条件が揃う可能性のあるのは 蒸発部ということになろう.

蒸発部管内が乾く状態はどんな場合に生 ずるのだろうか.

a. 主機通常運転中の意困的な空だき

b. 低負荷運転時の排エコ運転停止

c. 主機と排エコの同時運転停止

d. 蒸発管破孔事故による午水の漏出

e. 循環ポンプの機能そう失

a.の場合は起りにくい. 現在ではスート ファイアの危険性は排エコメーカによく認 識されており，排エコ運転のインストラク ションには，空だき運転は避けるように明 確に指示されている. したがって船の乗組 員がインストラクションに従う限り, 空だ
表 3 各伝熱セクションの状況比較

\begin{tabular}{|c|c|c|c|}
\hline & 外部污れ状況 & 雾囲気温度状況 & 伝熱面状況 \\
\hline $\begin{array}{l}\text { 予 } \\
\text { 熱 } \\
\text { 部 }\end{array}$ & $\begin{array}{l}\text { 污れ量最む多く, } \\
\text { 炭素含有量も高い. }\end{array}$ & $\begin{array}{l}\text { 水側, ガス側共に } \\
\text { 温度低い. }\end{array}$ & $\begin{array}{l}\text { フィン付管, } \\
\text { 循環ポンプ停止し } \\
\text { てもボィラ水詰っ } \\
\text { ており, 空になる } \\
\text { 状態は起りにくい. }\end{array}$ \\
\hline $\begin{array}{l}\text { 蒸 } \\
\text { 発 } \\
\text { 部 }\end{array}$ & $\begin{array}{l}\text { 污れ量中間. 排ガ } \\
\text { ス出口側程污れ多 } \\
\text { く, 予熱部からの } \\
\text { 落下すす留りやす } \\
\text { い. } \\
\text { すすの炭素含有量 } \\
\text { 高い. }\end{array}$ & $\begin{array}{l}\text { 中間で自然発火の } \\
\text { 可能性は高くない. } \\
\text { しかし他の火種に } \\
\text { よる発火可能性が } \\
\text { ある. }\end{array}$ & $\begin{array}{l}\text { フィン付管, } \\
\text { 循環ポンプの運軽 } \\
\text { 管理によっては, } \\
\text { 管内が空になる可 } \\
\text { 能性がある. }\end{array}$ \\
\hline $\begin{array}{l}\text { 過 } \\
\text { 熱 } \\
\text { 部 }\end{array}$ & $\begin{array}{l}\text { 污れ量少ない. } \\
\text { 付着物の主成分は } \\
\text { 硫酸カルシウムで, } \\
\text { 炭素は少ない. }\end{array}$ & $\begin{array}{l}\text { 最も高温で, 自然 } \\
\text { 発火の可能性があ } \\
\text { る. }\end{array}$ & $\begin{array}{l}\text { フィン付管少なく, } \\
\text { 裸管の使用多い. } \\
\text { 管内は常に乾いた } \\
\text { 状態. }\end{array}$ \\
\hline
\end{tabular}

き運転は行われるはずはないからである.問題はb.の場 合で，表 1 であこのケースが最あ多かった. 低負荷運転 で，排エコを機能させるには排ガス量不足で運転を止め る場合, 排ガス温度が低下して予熱部などの低温腐食が 心配で運転を止める場合，あるいは出入港時で運転を止 める場合など，いろいろな事情でこのケースは生じ得る. いかに低負荷運転であっても排ガスが排エコに通されて いると, 蒸発部は飽和水が循環しているのであるから管 内は沸騰状態にある. 沸騰が生じていれば蒸発部出口の ボイド率は 1 亿近くなっており, 蒸発部内の午水保有量 は蒸発部管内容積の半分程度になっているとみれよう. この状態で循環ポンプを停止すると蒸発部の上の部分は 部分的に空だきの状態になろう.乙うなるとこの部分の 伝熱は低下し，すすの温度が上昇して発火の可能性も高 くなり，もし着火すれば二つの条件が揃うことになる. c.の場合はb.と似た状況である. 主機を停止しても排ガ ス温度は急には下がらない. 図 8 は主機停止後の排ガス 温度の変化を測定した例 ${ }^{4)}$ であるが, 停止後 2 時間経っ ても $200^{\circ} \mathrm{C}$ 程度にしか下がらない.したがって主機停止

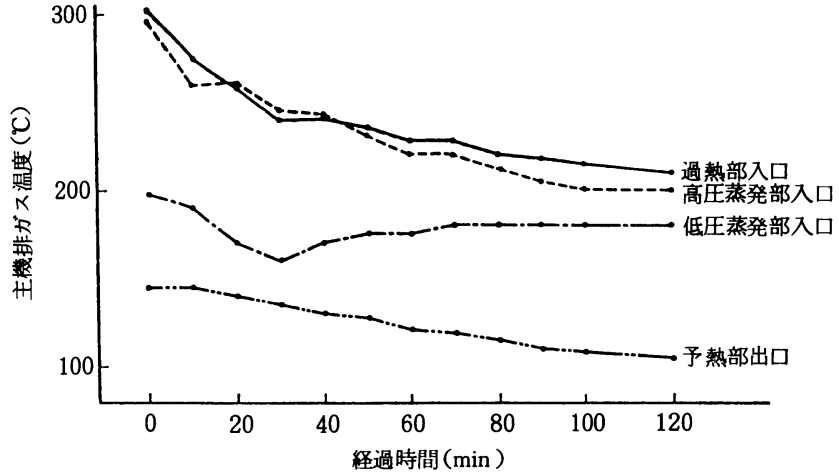

図 8 主機停止後の排ガス温度の変化 ${ }^{4)}$ 
後かなりの時間蒸発部は沸騰状態が続くから, 循環ポン プを止めると蒸発部は部分的に空だき状態になり， b.の 場合之同様の心配が生ずるだろう. d., e.は他の事故が 原因でスートファイアが誘発される場合である．e.は循 環ポンプの故障の他に，例えば, スートブローなどのた めに一時的に多量の蒸気を消費して蒸気圧力が急減し， 循環ポンプ吸込側管内で自己蒸発を起して循環が阻害さ れる，というようなケースも想定される.

以上蒸発管内が乾く状態が生じる場合について検討し たが, 表 1 の事故例でみた特徵から判断して, 注意すべ きはb.やc.の場合ではないかと思われる.

\section{4. スートファイア防止のための保全}

前章でみたように, スートファイアが生じるには，未 然炭化水素を多量に含んだすすの堆積, 及びボイラ管内 が乾いた空だきの状態の 2 条件が揃わねばならない，防 止の保全策はしたがって両条件又はいずれか一つの条件 が整わないようにすることである.

4.1 外部污れの防止と除去 外部污れそのもの を減すには排ガス中のすすの量を減さねばならないが， これはディーゼル主機の燃焼に係わる問題で, 排エコ側 ではコントロールできない，最近主機燃費率向上策の一 環で燃焼改善策(例えば水エマルジョン燃焼)が検討され ているが、こうした方策が将来排エコの外部污れ減少に あ良い結果をもたらす可能性がある. 排エコ側としては, できるだけ污れにくいような管配列やフィン形状を考慮 するという消極的対策を講じざるを得ないが，それはす でにいろいろ工夫されている. 積極的に污れの防止を考 えるとすれば，排エコの上流侅当な集じん装置を設置 し，排エコ手前で排ガス中からすすを除去することであ ろう. 未燃炭化水素粒子は主に慣性衝突によって排エコ 伝熱面に付着してくると考えられるから，10 ミクロンオ 一ダ以上のかなり大きな粒子のはずである.したがって 機械式集じん装置でも一定の除去効果が期待できると思 われる.

見時点では堆積したすすを除去する対策が中心となる. 排エコの大形化, フィン付管の使用で, 外部污れ対策の 必要性が增しているてとは排エコメーカによって良く認 識されており，すすの除去や洗浄の方法について様々な 工夫がなされている、スートブロワあ在来方式の改善や 強化に加えて，水噴霧流方式や鋼球を撤布する方式など 新しいあのあ開発され使用されている. 未燃炭素粒子を 主とする污れであれば, 堆皘したすすの付着力はそれほ ど強くなく，適切なスートブロワであればかなり除去さ れるはずである．新方式のスートブロワは効果的だが, 在来方式であ設置数の增大, 定置回転式から抜差式への 転換などで除去能力を強化することにより，過度の污れ の発達は防止できるだろう．スートブロワそのあのの強 化と別に，その運用に関わる保全あ注意されるべきであ る. スートブロワは最も故障の多い機器の一つである.
確実なスートブロー作業の実施を保証できる保守管理む 大切である.

しかしスートブロワだけではすすの除去は困難で, 完 全を期すには水洗が重要である. 水洗は入港停泊時に予 熱部上部から散水して行われる場合が多い. しかし現在 の所水洗が最む確実な污れ除去方法である以上, 専用の 常設専用ノズルを設ける，水洗作業を自動化するなどし て, 乗組員が水洗しようと思えば直ちに簡単に実施でき るように水洗装置を強化する必要があるように思われる. できれば水スートブロワのような考え方を導入し，主機 運転中であ水洗できるようにするのが望ましい，水洗の 場合付着物中の硫酸成分の溶出水による腐食という二次 障害を避けるために，伝熱面全体が確実に水洗されるよ うに実施するのが大切である.

スートファイア発生場所が蒸発部管群上半部に集中し ているから, スートブロワ, 水洗いずれの場合も, とく にての部分の管群の污れ除去に注意すべきである. 水洗 する場合む単に排エコ上部からの散水でなく，乙の管群 部に直接散水できる方法を構じる必要むあろう. 污れ状 況は，全体は当然ドラフトロスから監視することになる が, この管群部に観測空を設け, 目視監視を強める必要 ああろう.

4.2 運転上の留意点一言でいえば, 空だき状 態が生じるような運転操作を避ける，ということにつき る. 伝熱管内に水が存在していれば，たとえすすが着火 してあ溶損するまでには到らないと考えられるからであ る. 平常航海中の空だきは論外として, 問題はさきにみ たb.やc.のような低負荷運転時, 主機停止時, 出入港 時，また何か他の故障などで主機や排エコの運転の停止 に迫られる時など，特別な状況の場合である. こういう 場合であ循環ポンプを停めず，ボイラ管に通水を続けて おくことが大切である. 低負荷運転で排ガス温度や排ガ ス流速が低すぎて污れの増大や低温腐食が心配とすれ ば，バイパスダクトを設けて一定の主機負荷以下では排 ガスを通さないようにする措置が必要だろう.

すすが発火した場合を想定して，それを早期に発見す る対策も考えられる. 現在講じられているのは排ガス温 度の監視であるが, その監視位置は排エコ出口よりも蒸 発部管群近傍が適切といえよう.

\section{5. おわりに}

スートファイアの事故発生確率は高くない. したがっ てそれほど大きく問題にする事故とはいえないのかもし れない.しかしいったん生じると大規模な事故になるの で外部污れに関わる排エコの典型的な障害の一つとして 取りあげてみた.

ここでは過去の事故例をみて, 何らかの原因で “空だ き”状態になるのがスートファイアの主要な発生要因で あるとしたが, すべてがそうだとは断定できない，スー トファイア発生時の詳細な記録が少なく，不明な点が多 
いからである. しかしうえの見方で対処すればスートフ アイアはほぼ防止できるのではなかろうか. 現在のよう な性状のディーゼル主機排ガス中に設置される排エコで は, 伝熱面へのすすの堆積とその着火の可能性をゼロに するのは難しい. したがってそれを運転する船の側で， 空だき状態が生じないよう，常に運転操作上の配慮をな されるととが望まれる.

終りに，スートファイア事故例のデータ収集で，造船
所，船会社の方々ので協力を頂きました，感謝する次第 です.

\section{文献}

1) Mulcathy, M.F.R., et al., J. Inst. Fuel, (1966), 385

2) Bishop, R.J., J. Inst. Fuel, (1968), 51

3）日本造船研究協会, 研究資料 No. 89, 第 92 研究部会ボ 亏外部污れに関する基礎調査報告書 (1969)，36.

4）横山ほか 4 名, 三菱重工技報, Vol. 17, No. 3 (1980), 1 . 